\title{
PAI TEACHER COMPETENCE CONCEPT OF AYYUHAL WALAD PERSPECTIVE
}

\author{
Ashif Az Zafi \& Muhammad Shidqul Wafa \\ IAIN Kudus \\ ashifazzafi@iainkudus.ac.id,mshidqulwafa@gmail.com
}

\begin{abstract}
The purpose of this study is to describe the concept of PAI teacher competence, propose the concept of $P A I$ teacher competence from the perspective of the Ayyubal Walad book and analyze the implications of the impact of the PAI teacher competence concept in the Ayyuhal $W$ alad book. This research is included in the library research method by collecting, citing and analyzing using data collection analysis from the literature that is representative and relevant to the discussion. The results of this study indicate that the concept of teacher competence is dominated by the competence of the teacher's personality.
\end{abstract}

Keywords: Competence, PAI Teacher, Ayyuhal Walad.

\section{INTRODUCTION}

Talking about education means discussing the past, present and future. The past is related to the material which is an important component in education. Because the past will determine the present and so on. While the present is related to the process that we do in carrying out their respective roles as educational actors. All these components are interrelated and become a unity for the sake of a good education.

Education is a process of transferring knowledge and values from teachers as educators to students. National education has two main foundations, namely Pancasila and the 1945 Constitution and has a function to develop capabilities and form a dignified nation's civilization. Education is one of the key instruments to regulate the thinking of youth towards the ideology of the nation. ${ }^{1}$ So this illustrates that education also has a vital function in efforts to instill the ideology of a nation or state.

${ }^{1}$ Sheikh, Sajid Ullah dan Muhammad Abid Ali. 2019. Al-Ghazali’s Aims and Objectives of Islamic Education. Journal of Education and Education Development, Vol. VI, No. 1: 111. 
In addition, the educational process has the aim of educating the nation's life and developing the potential for religion, science, creativity, independence and democracy. ${ }^{2}$ Education is the most important sector in the development process of a country. Because through education, the next generation of government and society relay holders are created in a country. Education is also one of the media for character building for future generations of the nation. Therefore, components related to education must be professional according to their respective duties so that the educational process runs effectively and efficiently so as to create good students.

It was explained in the Outlines of State Policy (GBHN) in 1993, that national education aims to improve human quality, namely humans who believe and fear God Almighty, have noble character, have personality, are independent, advanced, tough, intelligent, creative. and skilled, disciplined, work ethic, professional, responsible and productive as well as physically and mentally healthy. The purpose of education is actually contained in the notion of education. According to Shaykh Muhammad al-Naquib al-Atta, education in the Islamic sense is something special only for humans. This statement indicates that philosophically Islamic education should have a clear and firm conception of human beings. That education in Islam is only for humans. Muhammad Munir Morsi called it " insan kamil ". Insan Kamil does not only have a vertical dimension, but also has a horizontal dimension. Education in this framework is a process of human efforts to develop all potential, both physically (hominization) and spiritually (humanization) in order to become a completely balanced person, as a good citizen, and ready to accept and preserve and develop the nation's culture (socialization). ${ }^{3}$

In order for the transfer of knowledge and values to run well, competence is needed as a support and supporter. Teachers are required to have competencies according to their respective fields which include pedagogic, personality, professional and social competencies. The pedagogic competence of teachers in each subject area

\footnotetext{
${ }^{2}$ Buto, Zulfikar Ali. 2016. Pengembangan Kompetensi Profesional Guru PAI di Aceh. Miqot: Jurnal Ilmu-Ilmu Keislaman, Vol. XL, No. 2: 371.

3 Afandi, Rahman. 2011. Tujuan Pendidikan Nasional Perspektif Al-Qur'an. Insania, Vol. XVI, No. 3 : 372-374.
} 
is the main focus of competence that must be met. ${ }^{4}$ Teachers as educators become agents of determining the success of a process in the implementation of education. Therefore, to achieve this success, an ideal teacher is needed, namely a teacher who must master the competence of knowledge, skills, values, attitudes and habits in thinking and acting well..$^{5}$ That is, an educator needs to have mature teacher competencies in order to achieve the goals and successes that have been prepared previously.

Educational institutions experience the dynamics of development with the demands of technological collaboration in the midst of modernity. ${ }^{6}$ This is a spur for formal educational institutions to continue to improve their capabilities and mobility in the midst of modernization so that these educational institutions receive a good response in the community to answer all problems in the field of education and the public's thirst for quality in an educational institution. Without realizing it, educational institutions that follow the flow of modernity will last and attract students in the community.

Madrasah education units from primary to secondary levels have differences with other educational institutions, namely the Islamic character which also continues to carry out general material development. Islamic education must be able to produce the output of students who are knowledgeable and continue to develop themselves so that they are appropriate and in line with the development of knowledge and technology. ${ }^{7}$ This development of Islamic character is a differentiator for madrasas compared to other formal school-based educational institutions. The difference arises from the Islamic religious education material taught in madrasas that is delivered more specifically from the field of study and substance. The specifications or peculiarities of Islamic religious education materials in madrasas include the study of Akidah Akhlak, Al-Qur'an Hadith, Jurisprudence and History of Islamic Culture.

${ }^{4}$ Ismail. 2015. Peningkatan Kompetensi Pedagogik Guru PAI dalam Pembelajaran. Jurnal Mudarrisuna, Vol. IV, No. 2: 704.

${ }^{5}$ Buto, Zulfikar Ali. 2016. Pengembangan Kompetensi Profesional Guru PAI di Aceh, 371.

6 Taruna, Mulyani Mudis. 2011. Perbedaan Kompetensi Guru Pendidikan Agama Islam (Studi Komparasi Guru PAI Tersertifikasi dan Belum Tersertifikasi di MTs Kabupaten Banjar Kalimantan Selatan. Jurnal Analisa, Vol. XVIII, No. 2: 181.

${ }^{7}$ Suriadi, dkk. 2020. Professionalism of Teacher (An Overview of The Hadiths and Islamic Education Experts). Edukasi, Vol. VIII, No. 2: 113. 
Through the specification of the field of study, it has consequences for teachers in the field of study that are adjusted to the competencies according to the four clusters of Islamic religious education studies, namely educators or teachers who specifically teach Akidah Akhlak different from teachers who teach in the field of study of Al-Qur'an Hadith, Jurisprudence and Islamic Cultural History.

An educator or teacher at a formal madrasah educational institution is someone who has competence as an educator and has been declared competent and able to carry out his duties as a professional educator in accordance with the guidelines of the position. Through Ministerial Regulation No. 18 of 2007, the Government views that it is necessary to provide teacher certification to avoid mismatches while at the same time having pedagogical, professional, social and personal competencies.

In addition to pedagogical, professional, social and personal competencies, educators or teachers must be equipped with good character competencies because a teacher will later become uswatun hasanah for their students. This moral demand is much more important because through educational activities there is a transfer of value. The character of the students being taught will be formed when the educator or teacher has and implements the character according to the Islamic image. This is because madrasas have religious characteristics. Madrasas are also the center for the implementation of two educations, namely the general education center and the Islamic education center. ${ }^{8}$ The character competencies of these educators or teachers will later become role models for students. Therefore, it needs to be internalized by educators or teachers as an effort to continue to learn and develop the abilities and competencies of educators or teachers' character. ${ }^{\text {? }}$

Today, the character competencies of educators or teachers who can be role models for their students are starting to erode with the currents of time and

8 Kisbiyanto dan Setyoningsih. 2018. Strategic Values in Madrasa Development in Kudus (Management Study of Islamic Education Perspective in Nusantara). Jurnal Addin, Vol. XII, No. 2: 474.

${ }_{9}^{9}$ Ma'arif, Muhammad Anas. 2017. Analisis Konsep Kompetensi Kepribadian Guru PAI Menurut AzZarnuji. Istawa: Jurnal Pendidikan Islam, Vol. II, No. 2: 37. 
globalization. The values of Islamic character competence of educators or teachers are often forgotten, which is feared to have an impact on the role model that students will follow. The essence of the material contained in the classic book ayyuhal walad teaches discipline and mutual respect between educators or teachers and students. To that end, PAI teacher should not only fo $\mathrm{c}$ us in meeting the pedagogical competence, professional, social and personal, but also must meet komepetensi character and values of Islam which in this case is contained in the book Ayyuhal walad are still relevant to be used as guidelines for educators or teachers, especially PAI teachers and students.

This study aims to determine the concept of PAI teacher competence from the perspective of the ayyuhal walad book, to know the factors that influence the competence of PAI teachers and to know the implications of the impact of the concept of Islamic education in the ayyuhal walad book. Competence in general can be interpreted as an individual who is capable, powerful, authoritative, has the skills and knowledge that needs to be possessed to assist in carrying out certain tasks. ${ }^{10}$ The term has become familiar in various lines of life, especially in the field of education. The term competence in the world of education emerged after certification and the development of technology so that it required PAI teachers to have competence in the field of technology in addition to their main competence as PAI teachers.

Teachers are at the forefront in the effort to change in society as an educator or teacher fighting and moving in the field of education in which education has a mission to provide knowledge and value ( value ) so that the public, especially learners can progress towards a better direction. Especially for religious teachers or PAI teachers who have a vital role in instilling religion and Islam as well as educating the mental and good character of students. PAI teachers are expected to be able to instill items of faith in their students and help develop them in religious practice and daily life.

\footnotetext{
10 Taruna, Mulyani Mudis. 2011. Perbedaan Kompetensi Guru Pendidikan Agama Islam (Studi Komparasi Guru PAI Tersertifikasi dan Belum Tersertifikasi di MTs Kabupaten Banjar Kalimantan Selatan, 181.
} 


\section{RESEARCH METHOD}

This article focuses and specifically examines the competence of PAI teachers from the perspective of the ayyuhal walad book. The focus of this research discusses the concept of PAI teacher competence contained in the book ayyuhal walad and the views of Imam Al-Ghazali regarding the competence of educators or teachers in the book written and made by Imam Al-Ghazali. The research was conducted using the literature study method by collecting and combining secondary sources with primary sources. The primary literature used is the book of ayyuhal walad which is supported by primary sources such as the book of ta'limul muta'allim , books and articles in local and international journals. The collected literature data is then processed and compared with the primary literature source, namely the ayyuhal walad book .

\section{RESULTS AND DISCUSSION}

\section{Teacher Competence}

Competence comes from English, namely competency which means knowledge, skills, and abilities. In line with that, competence in Arabic is kafa'ah Ahliyah which means skill and ability. Meanwhile, in the Big Indonesian Dictionary, competence is the authority, power to determine or decide something. ${ }^{11}$ If examined more deeply, ability or competence turns out to have a fairly broad meaning. Because ability is not merely showing skills in doing something, more than that, this ability can be observed through knowledge, appearance or performance, activities that use clear procedures or techniques and the results achieved. ${ }^{12}$ Elliot suggests that competence can be defined as a condition or quality of effectiveness, ability, or success.

Competence is an adequate task for the possession of knowledge, skills and abilities required by one's position. ${ }^{13}$ Competence also means knowledge, skills and

\footnotetext{
${ }^{11}$ Rofa'ah, Pentingnya Kompetensi Guru dalam Kegiatan Pembelajaran dalam Perspektif Islam, (Yogyakarta: CV. Budi Utama, 2012), 30.

12 Sumiati dan Asra, Metode Pembelajaran, (Bandung: Wacana Prima, 2008), 242.

${ }^{13}$ Rostieyah, Masalah-Masalah Ilmu Keguruan, (Jakarta: Bina Aksara, 2001), 4.
} 
basic values that are reflected in the habits of thinking and acting. ${ }^{14}$ The definition of this competence, when combined with a profession, namely a teacher or teaching staff, then the competence of an educator or teacher implies the ability of an educator or teacher to carry out obligations responsibly and appropriately or the ability and authority of an educator or teacher in carrying out the profession. his teacher. ${ }^{15}$ According to Drexel, someone who has competence is someone who is always results-oriented, pays attention to procedures in identifying and assessing the results of the learning process, has experience, formal and informal knowledge, and behaves towards progress. ${ }^{16}$

Personal competence of educators or teachers according to Government Regulation number 19 of 2005 concerning National Education Standards in article 28 paragraph 3 point $b$ states that what is meant by personality competence is personality abilities that are stable and stable, mature, wise and wise and can be role models for students. and virtuous. ${ }^{17}$ This definition of educator or teacher competence is a set of mastery of abilities that must exist in an educator or teacher in order to realize their performance effectively. However, if the notion of educator or teacher competence is associated with Islamic religious education, it is education that is very important for the lives of students, especially in achieving inner peace and mental health in general. Islam is the most perfect guide for life, the most powerful deterrent to wrong and evil deeds, the incomparable moral controller. Therefore, the competence of Islamic religious teachers is the authority to determine Islamic religious education to be taught at certain levels in the school where the teacher teaches. $^{18}$

In Islamic education that uses the Qur'an and Sunnah as a source of religious teachings and guidelines, indicators of personality competence of educators or teachers are found including expecting Allah's pleasure, honesty and trustworthiness, according to words and actions, fair, gentle and compassionate,

${ }^{14}$ Kunandar, Guru Profesional, (Jakarta: Raja Grafindo Perkasa, 2012), 52.

15 Usman. Moh, Menjadi Guru Profesional, (Bandung: PT Remaja Rosdakarya, 2005), 14.

16 Ismail, Moh. Ilyas. 2010. Kinerja dan Kompetensi Guru dalam Pembelajaran. Lentera Pendidikan, Vol. XIII, No. 1: 55.

${ }^{17}$ Ma'arif, Muhammad Anas. 2017. Analisis Konsep Kompetensi Kepribadian Guru PAI Menurut AzZarnuji, 38.

${ }^{18}$ Daradjat, Zakiah, Pendidikan Islam dalam Keluarga dan Sekolah, (Bandung: Ruhama, 1995), 55. 
humble, patient, Husnudzon, forgiving and tolerant. ${ }^{19}$ Ahmad Tafsir $^{20}$ states that the personality competence of an educator or teacher is the ability of a teacher which contains personality traits including affection, gentleness, humility, respect for knowledge, fairness, critical thinking, simple and committed to his words and actions. Putra Daulay Haidar ${ }^{21}$ states that the personality possessed in the teacher's personality competence is sincere, loves students, becomes a role model for students, is objective, has stable emotions, tawadlu' and qona'ah. Teachers who have good personality competencies are certainly a coveted hope for the world of education. The goal is that students can imitate the good personality of the teacher because a teacher is actually a role model and a reflection of students.

More than that, KH. Hasyim Asy'ari ${ }^{22}$ states that the competence of the teacher's personality is broader, namely the teacher needs to have the nature of muroqobah to Allah, sakinah, tawadlu', khauf, wara', tawakkal , glorifying knowledge, guarding oneself from humiliating acts according to the Shari'a, perpetuating sunnah such as regularly reading the Qur'an 'an, has a commendable character, is not shy about asking questions, is not materialistic, zuhud, gets along with the community, is passionate about ijtihad, researches and composes useful writings.

Al-Ghazali argues that there are no details of certain requirements to become a teacher, but there are many tasks that must be carried out and teachers must be able to carry out these responsibilities and duties. There are eight duties and responsibilities of teachers, namely presenting a sense of affection to students as a father's love for his child, being sincere in conveying learning material, giving advice to learn primary science before secondary and gradually, preventing students from disgraceful actions, not criticizing other sciences in front of students, teaching science to students according to their level of ability, not teaching details and details to people who have not been able to understand them and teachers must be able to

\footnotetext{
${ }^{19}$ Ramayulis, Profesi dan Etika Keguruan (Jakarta: Kalam Mulia, 2013), 72.

20 Tafsir, Ahmad, Ilmu Pendidikan Islam, (Bandung: PT Remaja Rosdakarya, 2013), 134.

${ }^{21}$ Haidar, Daulay Putra, Pendidikan Islam dalam Perspektif Filsafat (Jakarta: Prenada Media Grup, 2014), 107.

${ }^{22}$ Rosidin, Pendidikan Karakter Pesantren: Terjemah Adaptif Kitab Adabul Alim Wal Muta'allim Karya KH. Hasyim Asy'ari (Malang: Litera Ulul Albab, 2013), 90.
} 
be role models for their students. ${ }^{23}$ The actions and words of a teacher will certainly be an example for students, so the teacher needs to keep his actions and words so that students can imitate the good things reflected by the teacher. This is because teachers and students are dual, where the glory of the teacher is reflected through his dedication and treatment to students in interactions inside and outside the learning process. ${ }^{24}$ In the perspective of Islamic education, a good teacher who has competence as a teacher is a teacher who can be responsible for his duties. In addition, teachers in the perspective of Islamic education should have piety to Allah, have knowledge, have physical and spiritual health, have good morals, can be responsible and have a high social spirit. ${ }^{25}$

The ability of teachers not only has personal excellence that is imbued with the virtues of life and noble values that are lived and practiced. However, a teacher should have pedagogical abilities or matters concerning the educational tasks of a teacher. Through these abilities, teachers have an important role in educational programs including as facilitators, motivators, motivators, lesson planners and become an inspiration for their students. ${ }^{26}$

An educator is a professional worker who is specially prepared to educate, motivate and guide students who have been entrusted by the parents of these students to be educated. ${ }^{27}$ According to etymology, educator comes from the basic word learners which means to maintain, care for and provide training so that a person has knowledge, manners, reason and has good morals. Educators in English are educators, and in Arabic they have many names, namely mu'allim , murobbi, mu'addib , mursyid and ustadz, of course with different meanings from each other. ${ }^{28}$ This is in line with the opinion of Imam Al-Ghazali who stated that the main task of educators is to perfect, clean, purify, and bring humans (students) to taqarrub ilallah, meaning that they can get closer to God. Islam also views that in general, the task of

\footnotetext{
${ }^{23}$ Shodiq, Muhammad Jafar, (2016), Pemikiran Pendidikan Al-Ghazali. Literasi, Vol.VII, No. 2: 146.

${ }^{24}$ Basri, Hasan, Filsafat Pendidikan Islam (Bandung: CV Pustaka Setia, 2009), 59.

${ }^{25}$ Daradjat, Zakiah, dkk, Ilmu Pendidikan Islam (Jakarta: Bumi Aksara, 2018), 41.

26 Trianto dan Titik Triwulan Tutik, Sertifikasi Guru dan Upaya Peningkatan Kualifikasi, Kompetensi dan Kesejabteraan (Jakarta: Prestasi Pustaka Publisher, 2007), 71.

${ }^{27}$ Wiyani, Noval Ardy, Ilmu Pendidikan Islam (Yogyakarta: Ar-Ruzz Media, 2016), 97.

${ }^{28}$ Ramayulis, Dasar-Dasar Kependidikan (Jakarta: Kalam Mulia, 2015), 135.
} 
the teacher is to educate, namely to seek the development of the potential of students including cognitive, affective and psychomotor potential. ${ }^{29}$

\section{Competency of Ayyuhal Walad Book Perspective Teacher}

In the book of Ayyuhal Walad, Imam Al-Ghazali uses three terms towards teachers, namely al-mu'allim (teacher), al-mudarris (educator) and al-walid (parents) . From this, the teacher or educator is someone who has the duty and responsibility in education and teaching to perfect, clean and guide students so that they can get closer to God. According to Al-Ghazali, educators or teachers must have four competencies including zuhud, namely the attitude of avoiding loving the world and rank, meaning that a teacher needs to leave worldly things. In addition, educators or teachers must also study with mursyid teachers. The purpose of this is that a teacher must study with a teacher in terms of science, with the meaning of maintaining a credible sanad and authenticity of knowledge. Al-Ghazali also stated that educators or teachers must be able to do riyadhah, which means reducing the pleasures of the world and increasing worship towards the hereafter, including reducing eating and drinking, talking and sleeping, and vice versa educators or teachers must worship a lot, give alms and fast. And finally, Al-Ghazali said that educators or teachers need to practice noble character. Because educators or teachers are role models for their students, educators or teachers must be able to practice noble character in everyday life. Among these noble morals are prayer, tawakkal, patience, gratitude, qanaah , wisdom, tawadhu', knowledgeable, honest, careful , gentle, humble, honest, authoritative and fulfilling promises. ${ }^{30}$

In Ihya' Ulumuddin, Al-Ghazali strengthens the competence of teachers by suggesting nine things, namely, teachers must be gentle and have compassion for their students, meaning that educators or teachers must love students as they love their own children. In addition, Al-Ghazali also stated that teachers should not demand wages from their students, not hide their knowledge, stay away from doing

29 Zainuddin, M., Pendidikan Islam dari Paradigma Klasik Hingga Kontemporer (Malang: UIN Malang Press, 2009), 167.

30 Al-Ghazali, Imam Abu Hamid Muhammad bin Muhammad, Ayyuhal Walad fi Nasibatil Muta'allimin wa Mauidzatibim li Ya'lamu wa Mumayyizu 'Iman Nafi'an Min Ghairibi, (Surabaya: Al-Hidayah, tt), 13-14. 
despicable morals, encourage students to avoid fanaticism, treat and understand the potential of their students well and discuss and work together. in terms of science. The thing that is no less important is that educators or teachers must remind and direct their students that the purpose of studying is to get closer to God and educators or teachers must instill faith in students. Among the competencies of educators or teachers proposed by Imam Al-Ghazali is dominated by the competence of the teacher's personality. So it can be said that the teacher's personality competence has a major influence on the achievement of educational goals. The personality competencies of both educators and teachers are expected to be able to dominate and can be used as role models by their students. Shaykh AzZarnuji stated that there are 12 indicators that become the competence of educators or teachers, namely sincerity, piety, humility, pious and warlike, having compassion, being authoritative, giving advice, being serious, not being jealous or envious, keeping ablution, praying. night and read the Qur'an.

According to Al-Ghazali, the personality competence of educators or teachers is very important by expressing the opinion that teachers must practice their knowledge, and the knowledge that is practiced must match the words and actions of the educator or teacher. Because students will see something that can be seen, namely the behavior of the teacher or teacher. So educators or teachers need to be careful and keep doing good so that they can be imitated by their students. Because in essence students are a shadow of the educator or teacher. If the object is straight, the image will be straight, and if the object is bent, the image will be bent. Likewise with educators and students, if the educator or teacher behaves well and uses knowledge, the students he teaches will follow suit with good behavior and behavior and use knowledge in every charity that is done.

\section{CONCLUSION}

The concept of competence Teacher PAI contained in the book Ayyuhal Walad work of Imam Abu Hamid Muhammad ibn Muhammad Al-Ghazali was ascetic and avoid the attitude of love the world to excess, must be studied to teachers mursyid to keep the sanad and the authenticity of the science that is credible 
, must be able to perform riyadhah with reducing the pleasures of the world and multiply worship to the afterlife and mengistiqomahkannya with m engurangi eat and drink, talk and sleep, as well as vice versa educator or teacher should be a lot of prayer, charity and fasting and the need to practice the noble character as educators or teachers become role models for their students, so Good morals certainly must be the main concern of educators or teachers to be implemented in everyday life.

\section{REFERENCES}

Afandi, Rahman. 2011. Tujuan Pendidikan Nasional Perspektif Al-Qur'an. Insania 16(3).

Basri, Hasan. (2009). Filsafat Pendidikan Islam. Bandung: CV Pustaka Setia.

Buto, Zulfikar Ali. (2016). Pengembangan Kompetensi Profesional Guru PAI di Aceh. Miqot: Jurnal Ilmu-Ilmu Keislaman 40(2).

Daradjat, Zakiah, dkk. (2018) Ilmu Pendidikan Islam. Jakarta: Bumi Aksara.

Daradjat, Zakiah. (1995). Pendidikan Islam dalam Keluarga dan Sekolah. Bandung: Ruhama.

Al-Ghazali, Imam Abu Hamid Muhammad bin Muhammad. (tt). Ayyubal Walad fi Nasibatil Muta'allimin wa Mauidzatibim li Ya'lamu wa Mumayyizu 'Tlman Nafi'an Min Ghairibi. Surabaya: Al-Hidayah.

Haidar, Daulay Putra. (2014). Pendidikan Islam dalam Perspektif Filsafat. Jakarta: Prenada Media Grup.

Ismail, Moh. Ilyas. (2010). Kinerja dan Kompetensi Guru dalam Pembelajaran. Lentera Pendidikan 13(1).

Ismail. (2015). Peningkatan Kompetensi Pedagogik Guru PAI dalam Pembelajaran. Jurnal Mudarrisuna 4(2).

Kisbiyanto dan Setyoningsih. (2018). Strategic Values in Madrasa Development in Kudus (Management Study of Islamic Education Perspective in Nusantara). Jurnal Addin 12(2).

Kunandar. (2012). Guru Profesional. Jakarta: Raja Grafindo Perkasa.

Ma'arif, Muhammad Anas. (2017). Analisis Konsep Kompetensi Kepribadian Guru PAI Menurut Az-Zarnuji. Istawa: Jurnal Pendidikan Islam 2(2).

Ramayulis. (2013). Profesi dan Etika Keguruan. Jakarta: Kalam Mulia.

Ramayulis. (2015). Dasar-Dasar Kependidikan. Jakarta: Kalam Mulia.

Rofa'ah. (2012). Pentingnya Kompetensi Guru dalam Kegiatan Pembelajaran dalam Perspektif Islam. Yogyakarta: CV. Budi Utama.

Rosidin. (2013). Pendidikan Karakter Pesantren: Terjemah Adaptif Kitab Adabul Alim Wal 
Muta'allim Karya KH. Hasyim Asy'ari. Malang: Litera Ulul Albab.

Rostieyah. (2001). Masalab-Masalah Ilmu Keguruan. Jakarta: Bina Aksara.

Sheikh, Sajid Ullah dan Muhammad Abid Ali. (2019). Al-Ghazali's Aims and Objectives of Islamic Education. Journal of Education and Education Development 6(1).

Shodiq, Muhammad Jafar. (2016). Pemikiran Pendidikan Al-Ghazali. Literasi 7(2).

Sumiati dan Asra. (2008). Metode Pembelajaran. Bandung: Wacana Prima.

Suriadi, dkk. (2020) Professionalism of Teacher (An Overview of The Hadiths and Islamic Education Experts). Edukasi 8(2).

Tafsir, Ahmad. (2013). Ilmu Pendidikan Islam. Bandung: Remaja Rosdakarya.

Taruna, Mulyani Mudis. (2011). Perbedaan Kompetensi Guru Pendidikan Agama Islam (Studi Komparasi Guru PAI Tersertifikasi dan Belum Tersertifikasi di MTs Kabupaten Banjar Kalimantan Selatan. Jurnal Analisa 18(2).

Trianto dan Titik Triwulan Tutik. (2007). Sertifikasi Guru dan Upaya Peningkatan Kualifikasi, Kompetensi dan Kesejabteraan. Jakarta: Prestasi Pustaka Publisher.

Usman. Moh. (2005). Menjadi Guru Profesional. Bandung: PT Remaja Rosdakarya.

Wiyani, Noval Ardy. (2016). Imu Pendidikan Islam. Yogyakarta: Ar-Ruzz Media.

Zainuddin, M. (2009). Pendidikan Islam dari Paradigma Klasik Hingga Kontemporer. Malang: UIN Malang Press. 